Marquette University

e-Publications@Marquette

5-1-2007

\title{
Akerlof and Kranton on Identity in Economics: Inverting the Analysis
}

John B. Davis

Marquette University, john.davis@marquette.edu

Accepted version.Cambridge Journal of Economics, Vol. 31, No. 3 (May 2007): 349-362. DOI. (C) 2007 Oxford University Press. Used with permission. 


\title{
Akerlof and Kranton on Identity in Economics: Inverting the Analysis
}

\author{
John B. Davis \\ Department of Economics, Marquette University \\ Milwaukee, Wi
}

\begin{abstract}
The concept of identity was introduced into the neoclassical utility maximising framework by Akerlof and Kranton in an analysis which draws directly from social psychology's social identity approach and self-categorisation theory. This paper examines their analysis, and compares the social identity approach and an alternative social psychology identity framework called the sociological approach to identity. Using this comparison, the paper argues that their treating identity as an argument in the utility function leaves unaddressed how individuals' different social identities are related. The paper suggests a framework for addressing this issue by embedding their utility function in a personal identity objective function. The general context for the paper is the AkerlofKranton analysis as an example of 'recent economics' defined as a collection of new competing research programmes that make departures from neoclassical economics.
\end{abstract}

Keywords: Identity in economics, Social identity approach, Sociological approach to identity, Personal identity objection function, Recent economics

\section{I ntroduction}

The concept of identity has been extensively investigated in psychology and sociology since the 1970 s but, with a few exceptions, has only recently begun to receive serious attention in economics. ${ }^{1}$ The 'Economics and Identity' paper of George Akerlof and Rachel Kranton (2000) represents an important contribution in

Cambridge Journal of Economics, Vol. 31, No. 3 (May 2007): pg. 349-362. DOI. This article is @ [Oxford University Press] and permission has been granted for this version to appear in e-Publications@Marquette. [Oxford University Press] does not grant permission for this article to be further copied/distributed or hosted elsewhere without the express permission from [Oxford University Press]. 
NOT THE PUBLISHED VERSION; this is the author's final, peer-reviewed manuscript. The published version may be accessed by following the link in the citation at the bottom of the page.

this regard in that it systematically introduces the concept of identity into the standard neoclassical framework by incorporating identity as an argument in the utility function. As such, the paper is characteristic of what I have termed 'recent economics', understood as a collection of new research programmes emerging in the last two decades, all of which have relied on significant imports of noneconomics science content to produce new arguments in economics (Davis, 2006). Akerlof and Kranton explicitly characterise their own analysis as one offering explanatory advantages by virtue of its drawing upon science content outside economics:

Because of its explanatory power, numerous scholars in psychology, sociology, political science, anthropology, and history have adopted identity as a central concept. This paper shows how identity can be brought into economic analysis, allowing a new view of many economic problems. (Akerlof and Kranton, 2000, p. 716)

By incorporating identity in standard utility function analysis, however, Akerlof and Kranton also differ from many of the new research strategies in 'recent economics' whose imports from other fields have produced significant departures from the standard neoclassical programme. Given the breadth and diversity of the investigation of identity and self concepts in psychology and sociology in recent years, this naturally raises the question as to the extent to which their imported contents reflect these fields versus the extent to which they reflect the limited opportunities available for introducing the concept of identity into neoclassical economics. I previously argued that neoclassical economics lacks an adequate account of the identity of the individual, because the utility function analysis lacks the resources to explain the individuation and re-identification of individuals (Davis, 2003). Thus a further question the Akerlof-Kranton borrowing of social psychology identity concepts raises is whether their treatment of identity rescues the standard neoclassical view of the individual.

In order to investigate these questions, I begin in the second section by briefly describing the main identity concepts which Akerlof and Kranton draw from psychology. In the third section, I explain how they use these concepts by describing their formal model, which treats identity as an argument in a standard utility function. In the fourth section, I describe the particular approach to identity in psychology on which they draw-social identity theory. ${ }^{2}$ In the fifth section, I describe a rival approach to identity from sociology which they do not employ-the sociological approach to identity. ${ }^{3}$ In the sixth section, I review the Akerlof-Kranton

Cambridge Journal of Economics, Vol. 31, No. 3 (May 2007): pg. 349-362. DOI. This article is @ [Oxford University Press] and permission has been granted for this version to appear in e-Publications@Marquette. [Oxford University Press] does not grant permission for this article to be further copied/distributed or hosted elsewhere without the express permission from [Oxford University Press]. 
NOT THE PUBLISHED VERSION; this is the author's final, peer-reviewed manuscript. The published version may be accessed by following the link in the citation at the bottom of the page.

framework in the context of differences between the two approaches to identity, and evaluate their concept of social identity in this light. The seventh section suggests an inversion of the Akerlof-Kranton framework that addresses the issue of how one can add an account of personal identity to their social identity analysis. The eighth section returns to the paper's opening theme to comment on the Akerlof-Kranton framework as an example of 'recent economics'.

\section{The Akerlof- Kranton identity concept}

The identity approach which Akerlof and Kranton employ is constructed out of ideas from two different areas of theoretical investigation in psychology. First, the particular concept of identity they employ is a social identity concept understood from the individual's point of view as the person's 'sense of self' or 'selfimage'. A person's self-image is multidimensional and is represented in terms of all the different social categories (ethnicity, gender, religion, etc.) assignable to the individual. Social categories are broad social science classifications used in academic research and by government agencies to describe widely recognised social aggregates. A person's 'sense of self' or 'self-image', then, is said to constitute his/her identity in the sense that, as Akerlof and Kranton put it, 'identity is bound to social categories; and individuals identify with people in some categories and differentiate themselves from those in others' (Akerlof and Kranton, 2000, p. 720; emphasis added). The idea of 'identifying with' others is what makes their concept of identity a social identity one. They are silent about the concept of personal identity or the idea of 'identity apart from' others. Note also that their particular view of social identity, namely that individuals identify with others in terms of social categories, is different from the idea that individuals identify with others through social structural phenomena such as groups, institutions and interpersonal relationships.

Second, Akerlof and Kranton draw on the psychodynamic theory of personality to explain how an individual's identity as self-image relates to behaviour.

This model can be expressed by ideas central to the psychodynamic theory of personality, found in almost any psychology text. In personality development, psychologists agree on the importance of internalisation of rules for behavior. Freud called this process the development of the superego. Modern scholars disagree with Freud on the importance of psychosexual factors in an individual's development, but they agree on the importance of anxiety that a person experiences when she violates her

Cambridge Journal of Economics, Vol. 31, No. 3 (May 2007): pg. 349-362. DOI. This article is @ [Oxford University Press] and permission has been granted for this version to appear in e-Publications@Marquette. [Oxford University Press] does not grant permission for this article to be further copied/distributed or hosted elsewhere without the express permission from [Oxford University Press]. 
NOT THE PUBLISHED VERSION; this is the author's final, peer-reviewed manuscript. The published version may be accessed by following the link in the citation at the bottom of the page.

internalised rules. One's identity, or ego, or self, must be constantly 'defended against anxiety in order to limit disruption and maintain a sense of unity'. (Akerlof and Kranton, 2000, p. 728) ${ }^{4}$

Social categories are associated with various rules of behaviour that individuals internalise in a process that constitutes the individual's identity or sense of self. When these internalised rules are violated (in ways that Akerlof and Kranton model in a game-theoretic setting), this generates a sense of anxiety on the part of the individual, leading to actions intended to reduce this anxiety, and thereby restore the individual's 'sense of unity'. Alternatively, they allow that the violation of internalised rules of behaviour generates 'cognitive dissonance' with the same effects.

Thus the concepts of 'personality', 'ego', 'self' and 'sense of unity' from the passage above are used in essentially the same way as the concepts of 'sense of self' and 'self-image' in that all refer to the identity of the individual understood in social identity terms. The former set of concepts, however, concern individual behavioural mechanisms, whereas the latter concepts concern the actual content of individual identity. That is, the individual's self-image has as its specific content all the different identifications with others which the individual has, while this selfimage functions by way of a psychological mechanism internal to the individual that produces the choices individuals make to reduce anxiety. Akerlof and Kranton suggest that this internal mechanism is inaccessible to individuals when saying that they use the verb 'choose' advisedly in their analysis, and 'do not presume one way or another that people are aware of their own motivations, as in standard utility theory which is agnostic as to whether an individual shopper is aware or not of the reasons for her choices' (Akerlof and Kranton, 2000, p. 719).

\section{I dentity or self-image as an argument in the utility function}

To model these concepts, Akerlof and Kranton incorporate identity in a standard utility function framework by treating identity or self-image as an argument in the utility function:

\section{Graphic (1)}

Here utility depends upon j's identity or self-image $\mathbf{I}_{\mathrm{j}}$ and also on j's actions $\mathbf{a}_{\mathrm{j}}$ and the actions of others $\mathbf{a}_{-j}$. Identity or self-image itself is defined as:

Cambridge Journal of Economics, Vol. 31, No. 3 (May 2007): pg. 349-362. DOI. This article is @ [Oxford University Press] and permission has been granted for this version to appear in e-Publications@Marquette. [Oxford University Press] does not grant permission for this article to be further copied/distributed or hosted elsewhere without the express permission from [Oxford University Press]. 
NOT THE PUBLISHED VERSION; this is the author's final, peer-reviewed manuscript. The published version may be accessed by following the link in the citation at the bottom of the page.

Graphic (2)

I dentity or self-image depends again on j's actions and the actions of others, upon j's assignable social categories $\mathbf{c}_{\mathrm{j}}$, upon j's own characteristics $\boldsymbol{\varepsilon}_{\mathrm{j}}$, and upon the extent to which j's own given characteristics match the social ideals of $\mathrm{j}$ 's categories, as indicated by recognised social prescriptions $\mathbf{P}$.

This interpretation of self-image should not be confused with a meaning often associated with the idea of self-image, namely, the individual's image of the self per se or of the self as a whole. In the Akerlof-Kranton approach, the self as a whole is the utility function itself, and $\mathbf{I}_{\mathrm{j}}$ does not depend on $U_{\mathrm{j}}$, that is, identity does not depend on having a sense of the oneself as a whole, but rather $U_{j}$ depends on $\mathbf{I}_{j}$. Self-image, in this respect, reflects matching relationships between certain characteristics of the individual and the ideal characteristics of certain social categories and, as such, concerns an aspect (or collection of aspects) of the self rather than the self per se. Another way of putting this point is to say that, despite the ordinary meaning of the term, identity as self-image in the Akerlof-Kranton model is not reflexive. In a reflexive relationship the subject takes a stance toward the subject him/herself, or the subject makes the entire subject his/her object, but here the subject not only takes no such a stance, but self-image is determined in terms of third-party observable relationships between the individual and social characteristics. Thus $\mathbf{I}_{\mathrm{j}}$ might better be labelled a social image of the self which the individual adopts rather than a self-image.

From this perspective, the Akerlof-Kranton modelling strategy can be compared to the standard extended utility function time allocation modelling strategy of Gary Becker and others (Becker, 1996). In Becker's analysis, personal and social capital are stocks of non-commodity wealth inherited and further produced with time and market goods such that individuals maximise utility given these stocks. Thus, one's various social identities might be considered an individual's social capital, and their sense of self-image might be considered the individual's personal capital. Akerlof and Kranton do not use the language of capital and investment in their paper, but their self-image function (2) operates like a production function, albeit in their model in a strategic, game-theoretic setting in which others' choices influence individuals' own choices, and in terms of their psychodynamic theory of personality, according to which individuals work to reduce anxiety and cognitive dissonance. That is, individuals construct their personalities or self-images (but not themselves) by using social prescriptions $\mathbf{P}$ as inputs that tell

Cambridge Journal of Economics, Vol. 31, No. 3 (May 2007): pg. 349-362. DOI. This article is @ [Oxford University Press] and permission has been granted for this version to appear in e-Publications@Marquette. [Oxford University Press] does not grant permission for this article to be further copied/distributed or hosted elsewhere without the express permission from [Oxford University Press]. 
NOT THE PUBLISHED VERSION; this is the author's final, peer-reviewed manuscript. The published version may be accessed by following the link in the citation at the bottom of the page.

them how to match their own characteristics $\boldsymbol{\varepsilon}_{\mathrm{j}}$ and their ideal characteristics according to the social categories $\mathbf{c}_{\mathrm{j}}$ assignable to them, all based on an internal technology of anxiety reduction.

Akerlof and Kranton's analysis is also like Becker's treatment of personal capital in that, in their framework, individuals engaged in anxiety or cognitive dissonance reduction effectively act to offset depreciation in personal capital selfimage stocks. But Akerlof and Kranton's analysis differs in that there is no mechanism in their case for actions in which the individual would also invest in personality or self-image capital, as is the case in Becker's learning-by-doing analysis in which, for example, larger stocks of music appreciation capital increase the satisfaction from listening to music, which then feed back into additional investment in music appreciation capital and so on. Rather, the Akerlof-Kranton model is homeostatic in character, in that it employs a regulatory feedback principle that serves to maintain a given personality stock or self-image state of the individual, where the regulator on maintaining the level of this stock balances the state of the individual's ideal social characteristics and of his/her assignable social categories $\mathbf{c}_{\mathbf{j}}$.

\section{Psychology's social identity approach}

As noted at the outset, of the variety of approaches to identity and the concept of the self in psychology and sociology, Akerlof and Kranton adopt what is known as the 'social identity' approach. The 'social identity' approach dates to the 1970s and the work of Henri Tajfel, whose thinking largely continues to define the approach (cf., Abrams and Hogg, 1999). Tajfel defined social identity as 'the individual's knowledge that he belongs to certain social groups together with some emotional and value significance to him of his group membership' (Tajfel, 1972, p. 292). Though a great deal has been published on social identity in the three decades since Tajfel's initial work, the framework continues to treat individuals' identity as their given social identity, as Tajfel did in terms of the different social categories into which individuals fall and to which they accordingly are seen as feeling they belong. The principal extension of the social identity approach today is 'self-categorisation theory' developed by J ohn Turner first in 1985, which elaborates a process whereby individuals come to see themselves in terms of certain social categories (Turner, 1985; Turner et al., 1987). Akerlof and Kranton follow this particular development in their explanation of social identity in terms of the individual's assignable categories. They depart modestly from the social identity literature in emphasising psychodynamic personality theory and the role of anxiety

Cambridge Journal of Economics, Vol. 31, No. 3 (May 2007): pg. 349-362. DOI. This article is @ [Oxford University Press] and permission has been granted for this version to appear in e-Publications@Marquette. [Oxford University Press] does not grant permission for this article to be further copied/distributed or hosted elsewhere without the express permission from [Oxford University Press]. 
NOT THE PUBLISHED VERSION; this is the author's final, peer-reviewed manuscript. The published version may be accessed by following the link in the citation at the bottom of the page.

in individual behaviour, neither of which figures per se as a theoretical construct for current proponents of the approach. However, the general motivational basis for explaining the self-categorisation processes in the social identity literature is not far removed. While the main emphasis in self-categorisation theory is upon cognitive processes and individuals' beliefs about themselves and social groups, there is also emphasis upon 'uncertainty reduction' as a core motivation, where this idea goes beyond an emphasis purely on cognitive behaviour (Hogg, 2001). Given, then, that Akerlof and Kranton use both anxiety reduction and cognitive dissonance reduction as mechanisms to explain behaviour, their recourse to psychodynamic personality theory seems not to add anything significantly different from what appears in the mainstream of psychology's current social identity theory.

From the beginning, it should be noted, the social identity theory literature has largely set aside the difference between the concept of an individual's social identity ('identifying with others') and the concept of an individual's personal identity ('identity apart from others'), though many contributors recognise the distinction. As the labels and descriptors imply, the former refers to commonalities between people within social categories as well as to differences between individuals in different social categories, whereas the latter refers to the self as being distinct from other people in general. According to Tajfel and others, the reason for their particular focus is that social identity theory originated in postwar European traditions in social psychology largely at odds with American ones, and in the view that social psychology explanations of collective phenomena are undermined when formulated in reductionist or individualist terms (Tajfel et al., 1984). ${ }^{6}$ A consequence of this for social identity theory research is that contributors who do recognise differences in the two identity concepts have generally put aside attention to how individuals' social and personal identities might relate to one another, how they might mediate one another, and how personal identity itself might be understood, suggesting that the latter concept might better be dealt with by philosophers, for whom it has long been an important concern. Thus, effectively the only concept of the self which the social identity literature employs is that of the collective or social self, such that individuals are loosely seen to be collections of social identities.

Not surprisingly, then, Turner's self-categorisation theory has as a central mechanism that people are 'depersonalised' in their adoption of social identities in that they come to see themselves as embodiments of group prototypes rather than as independent individuals. Turner does not take depersonalisation to imply, as might appear, that individuals are 'dehumanised' or 'deindividuated', meaning that

Cambridge Journal of Economics, Vol. 31, No. 3 (May 2007): pg. 349-362. DOI. This article is @ [Oxford University Press] and permission has been granted for this version to appear in e-Publications@Marquette. [Oxford University Press] does not grant permission for this article to be further copied/distributed or hosted elsewhere without the express permission from [Oxford University Press]. 
NOT THE PUBLISHED VERSION; this is the author's final, peer-reviewed manuscript. The published version may be accessed by following the link in the citation at the bottom of the page.

they are damaged or are have reduced well-being when identifying with others, but simply that they set aside their status as independent beings-as economists would say, ceteris paribus-when engaged in self-categorisation. One dimension of depersonalisation that deserves attention, however, concerns why and how any particular self-categorisation becomes psychologically 'salient' for an individual in the sense that the individual sees a given category as applying to him/herself (as well as the degree to which it is seen to apply). Clearly, individuals who have similar characteristics nonetheless differ in the extent to which they see themselves as members of certain groups. Why does one individual see him/herself as a member of some social group, while another with the same characteristics does not? The fact that like individuals can see themselves as members of the same social groups, but differ in how they give precedence to some groups over others, suggests that social identity does not exhaust individual identity, and that personal identity and social identity must be understood in relation to one another. In this respect, an important contribution is Tajfel's 'accentuation effect', whereby once it is given that individuals believe within some judgment dimension that a particular social category applies to them, they perceptually 'accentuate' both the similarities among stimuli falling within that social category and the differences between stimuli from that and other social categories (Tajfel, 1959). Tajfel developed his views with the aim of explaining such things as stereotyping, ethnocentrism, prejudice, and ingroup bias. Nonetheless, without a concept of personal identity, the main thrust of 'self-categorisation theory' and the social identity approach is to explain the effects of social categories on individuals per se, and less to explain how those categories become salient for individuals in the first place.

Finally, in its primary emphasis on cognitive processes, social identity theory, despite its name and apparent thrust, is a psychological theory, not a sociological one, as will become clearer in the next section when it is compared to the alternative sociological approach to identity with its primary emphasis on social relationships. Though the dividing lines within the field of social psychology on identity and self concepts between primarily psychological and sociological approaches are often blurred, and though the two types of approaches are complementary in important respects, there remain important differences between the two approaches that reflect their respective disciplinary origins. ${ }^{7}$ One difference that is particularly important here is that social identity theorists do not explain self-categorisation in terms of social structural interpersonal processes (whether between individuals or between individuals and groups of individuals), while this is the starting point for the sociological approach to identity. This is important because interpersonal processes presuppose some account of individual identity as

Cambridge Journal of Economics, Vol. 31, No. 3 (May 2007): pg. 349-362. DOI. This article is @ [Oxford University Press] and permission has been granted for this version to appear in e-Publications@Marquette. [Oxford University Press] does not grant permission for this article to be further copied/distributed or hosted elsewhere without the express permission from [Oxford University Press]. 
NOT THE PUBLISHED VERSION; this is the author's final, peer-reviewed manuscript. The published version may be accessed by following the link in the citation at the bottom of the page.

personal identity, since interpersonal interaction between individuals requires that they also be identified apart from or independently of their interaction, if we are to say who it is that is interacting. Thus, as will emerge in the next section, it is the sociological approach to identity, not psychology's social identity approach, which offers the outlines of an account of how social identity is related to personal identity. This difference will be seen to be important when we return to Akerlof and Kranton's reliance on psychology's social identity approach in accounting for identity in the utility function framework.

\section{The sociological approach to identity}

The central assumption of the sociological approach to self and identity is that there is an interactive reciprocal relation between the self and society in the sense that each influences the other. Individuals always act in social contexts and influence society through the groups, organisations and institutions, while society influences individuals through shared language meanings and other inherited social structures that enable individuals to interact, and take on social roles. Though the sociological approach has antecedents in the idea of the 'looking glass self' of Charles Cooley (1902) and the symbolic interactionist thinking of George Mead (1934), current work on identity generally follows the structural approach of Sheldon Stryker, which assumes, in contrast to Mead, that social structures-and thus the self and identity-are relatively stable (Stryker, 1980). ${ }^{8}$ The sociological approach to identity is thus different from the social identity approach for which social categories are social science classifications that subsume individuals under general designations whereas, in the sociological approach, social structure is conceptualised in terms of different types of social structural phenomenaespecially social groups-through which individuals interact. While individuals additionally recognise social categories as having social structural effects apart from their use in social science and indeed act with them in mind, social categories nonetheless constitute a relatively flat form of social structure by comparison with the multidimensional affiliations and associations individuals have with groups, organisations and institutions that themselves take on a variety of different forms, are hierarchically organised and have complex overlapping interconnections. One consequence of this, which is reflected in the sociological approach's central assumption that self and society are in interactive reciprocal relation to one another, is that individuals can be seen to have a status apart from how they are understood in social terms. Because there is such a vast variety of forms of social life, individuals cannot be explained in terms of their social characteristics alone, if they are to be seen as having any unity at all, and thus, metaphorically speaking,

Cambridge Journal of Economics, Vol. 31, No. 3 (May 2007): pg. 349-362. DOI. This article is (C [Oxford University Press] and permission has been granted for this version to appear in e-Publications@Marquette. [Oxford University Press] does not grant permission for this article to be further copied/distributed or hosted elsewhere without the express permission from [Oxford University Press]. 
NOT THE PUBLISHED VERSION; this is the author's final, peer-reviewed manuscript. The published version may be accessed by following the link in the citation at the bottom of the page.

individuals occupy an intersection or constitute something of a 'common denominator' to all these different social forms. Put in terms of identity analysis, individuals have personal identities as well social identities, and these two types of identities need to be seen as related.

Thus contributors to the sociological approach argue that treating social categories and social groups as the same is misleading, both because doing so obscures the different features of different kinds of social groups, which have different types of internal dynamic structures with different within-group behavioural implications for individuals, and because different kinds of social groups fit into overall social structure differently. Social groups, moreover, are usually structured in terms of different roles that account for the cohesion of the group, and individuals accordingly also have different types of relationships to the same social groups depending on the roles they occupy in those groups (Stets and Burke, 2000). A role identity is defined as 'the character and the role that an individual devises for himself as an occupant of a particular social position' (McCall and Simmons, 1978, p. 65). This combines the idea of pre-given social positions with their interpretation on the part of individuals. On the one hand, then, roles and positions are almost always subject to interpretation and negotiation while, on the other hand, individuals generally seek to match their own self-conceptions with the expectations others have of their roles. The negotiation of roles, however, also needs to be seen in the light of the overall structure of a set of roles within a social group. In the simplest setting, roles are paired with counter-roles (such as parent and child) while, in more complicated group and institutional settings (such as in business firms), roles are more highly differentiated, and have a variety of interconnections with one another. This all serves to remind us that people are individualised by their different relationships to social groups of which they are members. Accordingly, whereas psychology's social identity theory discussed above simply distinguishes between in-groups and out-groups, the sociological approach sees individuals as having multiple relations to others that cannot be collapsed along a single in/out axis.

This naturally brings up the issue of individuals' multiple identities or multiple social identities. The social identity approach recognises that individuals have multiple identities, but offers little to explain their interconnection. According to social science systems of social category classification, populations in different categories may occupy certain locations, populations may change in size over time, populations may overlap or any of number of possible statistical judgements may be made of social categories aimed at recording population characteristics. In

Cambridge Journal of Economics, Vol. 31, No. 3 (May 2007): pg. 349-362. DOI. This article is @ [Oxford University Press] and permission has been granted for this version to appear in e-Publications@Marquette. [Oxford University Press] does not grant permission for this article to be further copied/distributed or hosted elsewhere without the express permission from [Oxford University Press]. 
NOT THE PUBLISHED VERSION; this is the author's final, peer-reviewed manuscript. The published version may be accessed by following the link in the citation at the bottom of the page.

contrast, the sociological approach to identity seeks to explain individuals' social identity as the product of individual action within a social structure in virtue of the ways that different individual roles and positions relate to social structures. Individuals' social identities, then, are not simply a collection of characteristics that individuals contingently possess, but presuppose some causal account of how they have come to occupy positions in a particular social structure. Multiple identities, however, still remain a problem in the sociological identity approach. Like the social identity approach, it employs the concept of salience to explain how individuals favour certain identities over others. The language of salience, however, seems less an explanation of how or why individuals favour certain identities, and more simply a widely accepted terminology used to explain the fact that people do seem to favour certain social identities. I return to this issue below.

In any event, that individuals somehow favour certain identities is also central to the sociological approach to identity. The emphasis in the sociological approach, as suggested above, is on what individuals do as agents, how they actively negotiate their roles, and how their doing so creates their relationships with others. For example, in intragroup settings, individuals' self-conceptions reflect a sense of membership they set out to acquire for themselves, and activate for them what has been labelled a sense of 'self-efficacy' about what one does (Bandura, 1977). Self-efficacy is defined as having beliefs about one's ability to 'organize and execute the courses of action required to produce given attainments' (Bandura, 1997 , p. 3), or as having beliefs about one's competencies and one's ability to exercise them (Mischel, 1973). Individuals are also thought to have a sense of selfworth based on their relations to groups of which they are not members or groups to which they are outsiders. In such intergroup settings, individuals evaluate themselves favourably vis-à-vis outsiders as having a self-worth. In contrast to individuals' sense of self-efficacy, individuals' sense of self-worth appears to be more prey to contingencies beyond their control owing to events and circumstances that change the public standing of individuals' group characteristics (Crocker and Wolfe, 2001). But both self-efficacy and self-worth are still seen to be part of an individual's self-esteem, though the former appears more under the individual's own control, and thus casts the individual in a more active capacity. In any event, the sociological approach emphasises that individuals are agents.

Cambridge Journal of Economics, Vol. 31, No. 3 (May 2007): pg. 349-362. DOI. This article is @ [Oxford University Press] and permission has been granted for this version to appear in e-Publications@Marquette. [Oxford University Press] does not grant permission for this article to be further copied/distributed or hosted elsewhere without the express permission from [Oxford University Press]. 


\section{Akerlof and Kranton and the two approaches to identity}

Psychology's social identity theory, we saw, is explicitly rooted in a European tradition in social psychology that assumes that social psychology explanations of collective phenomena ought not to be formulated reductionistically in terms of individual behaviour. Indeed, it is partly for this reason that social identity theorists understand individual identity almost exclusively in social terms and do not systematically employ any concept of personal identity. Moreover, they are able to do this because their focus is strictly an individual's psychological process of selfcategorisation per se rather than any process of negotiating social relationships, as in the sociological approach to identity. Does this foundational assumption, then, create problems for Akerlof and Kranton's adoption of the non-individualist social identity approach for their methodological individualist utility function account of individuals' social identity?

This question needs to be considered in light of the fact that individuals have multiple social identifications. Both approaches to identity discussed in the last two sections assume that individuals' multiple social identities are ordered hierarchically according to a principle of salience, though neither explains just how such rankings actually come about or can change. In doing so, they make it possible, respectively, to ignore and not address the issue of how individuals' personal identities might function as means of organising individuals' multiple social identities. But if we take a more critical view of the matter, both approaches might rather be said to fail to explain social identification, because they lack an account of 'who' it is that has multiple social identities. That is, without some account of the 'bearer' of a set of social identities, saying that 'an individual' identifies with others is largely an empty claim. Indeed, without some account of the 'bearer' of a set of social identities the individual arguably fragments into a collection of unconnected social identities.

Note, then, that while Akerlof and Kranton also refer to the concept of salience, this concept plays a minor role in their analysis, because their gametheoretic models and examples of identity conflicts treat individuals as having but one (salient) social identity at a time (Green or Red in their prototype model), so that the issue of individuals having multiple social identities does not arise: 'When an individual's identity is associated with multiple social categories, the "situation" could determine, for example, which categories are most salient' (Akerlof and Kranton, 2000, p. 731n). Accordingly, their analysis of individual behaviour in their prototype model and its extensions works in terms of losses suffered by the individual associated with what they term identity externalities, but ignores possible

Cambridge Journal of Economics, Vol. 31, No. 3 (May 2007): pg. 349-362. DOI. This article is @ [Oxford University Press] and permission has been granted for this version to appear in e-Publications@Marquette. [Oxford University Press] does not grant permission for this article to be further copied/distributed or hosted elsewhere without the express permission from [Oxford University Press]. 
NOT THE PUBLISHED VERSION; this is the author's final, peer-reviewed manuscript. The published version may be accessed by following the link in the citation at the bottom of the page.

offsetting gains were individuals to re-rank their social identities (see ibid., pp. 727-31). This means that their model is quite limited in scope, especially since the social psychology literature provides considerable empirical evidence (if not complete explanations) that individuals in identity conflicts with others often reorder their rankings of different social identities rather than simply respond to others along the axis of a single social identity. By ignoring this kind of case, Akerlof and Kranton thus employ something akin to a partial equilibrium identity analysis, which has the virtue for them of effectively preventing the multiple social identifications issue and the 'bearer' problem from arising within their framework, but which means that their analysis has limited practical relevance.

This strategy might of course be thought a reasonable one, were they to identify the bearer of social identities as the individual utility function. The utility function is of course the individual's own utility function and, consequently, it might be argued, when incorporating social identity as an argument in the utility function, that an individual's many social identities must all belong to this self-same individual. This argument, however, is unsatisfactory, because the utility function cannot provide an account of personal identity. The (implied) argument that it does proceeds by explaining personal identity in terms of individual preferences, that is, that an individual can be identified in terms of his/her own preferences, because an individual's preferences are necessarily his/her own and no one else's. But this argument is circular, and presupposes what it is meant to explain, because it designates preferences as 'own' preferences. ${ }^{9}$ This means that individuality must be taken as exogenous in the neoclassical framework, or that individuals can only be taken to be independent of one another by stipulation. While this may suit economists' traditional goals of analysis in many standard contexts, the reliance on the utility function as the individual's objective function is more problematic for Akerlof and Kranton's social identity analysis which, by allowing for multiple social identities, needs to provide a more secure account of personal identity if they are to expand their game-theoretic behavioural analysis successfully beyond restricted and arguably unrealistic partial equilibrium-type examples. That is, without an account of personal identity, their framework lacks a representation of the unity of the self or the bearer of the individual's many social identities.

In this regard, the sociological identity approach offers valuable suggestions regarding how one might think about personal identity in non-atomistic, interactive social contexts. Recall that the central assumption of that approach is that there is a reciprocal relation between the self and society in which each influences the other. Or, focusing on individuals' side of this relationship, individuals being able to

Cambridge Journal of Economics, Vol. 31, No. 3 (May 2007): pg. 349-362. DOI. This article is @ [Oxford University Press] and permission has been granted for this version to appear in e-Publications@Marquette. [Oxford University Press] does not grant permission for this article to be further copied/distributed or hosted elsewhere without the express permission from [Oxford University Press]. 
NOT THE PUBLISHED VERSION; this is the author's final, peer-reviewed manuscript. The published version may be accessed by following the link in the citation at the bottom of the page.

influence society reflects their having an ability actively to negotiate their different social roles. Bandura and Mischel label this particular active ability self-efficacy, and the former explains it as the ability individuals have to 'organize and execute the courses of action required to produce given attainments' (Bandura, 1997, p. 3). This might seem to be essentially what many economists believe is involved in the act of choice in utility function analysis, but there are two key differences from that analysis. First, Bandura and other proponents of the sociological identity approach place emphasis on interpreting the agent as active in the sense of exercising abilities-a concept which does not standardly operate in the utility framework. Second, and more importantly, for social psychologists ability is always understood reflexively as an ability the individual exercises specifically in interactive social contexts in taking him/herself as a single object. ${ }^{10}$ Taking these two points together, it is possible to see the outlines of an account of personal identity in the sociological approach which would address the multiple social identities problem. On the one hand, when individuals in interactive social contexts reflexively take themselves to be a single object, they by definition form a conception of themselves independent of their multiple social identities. This self-conception then constitutes an elementary basis for explaining individuals' personal identities in relation to their social identities. On the other hand, that individuals are active in exercising this ability suggests that they manage this personal identity conception by organising their multiple social identities, perhaps by ranking and re-ranking them according to their view of a personal identity life plan worked out in their continual interaction with others. They do not, that is, simply find themselves locked into 'situations' over which they have no control, but actively negotiate these 'situations', and thereby make themselves the 'bearers' of their different social identities.

\section{I nverting the Akerlof- Kranton framework to add personal identity}

Here I suggest an alternative framework meant to capture the sorts of considerations advanced in the last section. The Akerlof-Kranton approach makes utility depend upon social identity in terms of (1), and then explains how the individual 'produces' social identity (game-theoretically) in terms of (2). But if, as suggested above in connection with the sociological approach, we were to treat the individual as being active in creating a personal identity, then we might rather say that the individual's objective function is a personal identity production function, which we could generate by inverting the Akerlof-Kranton framework to make personal identity reflect the 'utility' involved in the individual's negotiating his/her Cambridge Journal of Economics, Vol. 31, No. 3 (May 2007): pg. 349-362. DOI. This article is @ [Oxford University Press] and permission has been granted for this version to appear in e-Publications@Marquette. [Oxford University Press] does not grant permission for this article to be further copied/distributed or hosted elsewhere without the express permission from [Oxford University Press]. 
NOT THE PUBLISHED VERSION; this is the author's final, peer-reviewed manuscript. The published version may be accessed by following the link in the citation at the bottom of the page.

multiple social identities. That is, embedding Akerlof and Kranton's (1) and (2) in a new individual objective function seen as a personal identity production function would give:

Graphic (3)

This new $\mathbf{P} \mathbf{I}_{\mathrm{j}}$ function concerns j's personal identity as opposed to the $\mathbf{I}_{\mathrm{j}}$ function that concerns j's social identity or self-image. Making $\mathbf{P I}_{\mathrm{j}}$ a function of the individual's 'utility', which is itself a function of social identity, would essentially then tell us that the individual's production of personal identity involves preferences over the ranking and organisation of that individual's multiple social identities consistent with the individual sustaining a personal identity. However, these preferences would not need to be seen as psychological phenomenon, as in Akerlof and Kranton's anxiety or cognitive dissonance reduction model, but could rather be explained socially along the lines of the social preferences concept as associated with the individual's forms of interaction with and relations to others (Heinrich et al., 2004). Further, in addition to representing the individual as an active producer, the $\mathbf{P I}_{\mathrm{j}}$ personal identity production function can be seen to represent the individual as reflexive since, just as in standard neoclassical analysis, the individual takes the arguments of the utility function as objects, so here the individual takes the revised utility function itself as an object. Since $U_{j}$ constitutes a representation of the individual as a subject apart from the objective function itself, we can speak of $U_{j}$ as the subject's object, and then more fully regard $\mathbf{P I}_{\mathrm{j}}$ as a production objective function in which the individual actively constructs a personal identity by reflexively engaging with themselves in the form of their $U_{j}$ evaluation of their multiple social identities.

It should be emphasised, however, that $\mathbf{P I}_{\mathrm{j}}$ is not a full theory of personal identity, because there is little here to explain how and why individuals manage their personal identities other than that doing so involves organising their different social identities. Nonetheless, the $\mathbf{P I}_{\mathrm{j}}$ approach seems promising both because it makes central to the theory of the individual the idea that the individual works to sustain a personal unity in the face of potential fragmentation of the self, and because this work specifically concerns the individual's multiple social identities, thus squarely placing this view of the individual in the category of what I have previously referred to as a socially embedded individual conception (Davis, 2003). However, what more is involved in explaining personal identity than this, and further how specifically individuals might be thought to manage their different

Cambridge Journal of Economics, Vol. 31, No. 3 (May 2007): pg. 349-362. DOI. This article is @ [Oxford University Press] and permission has been granted for this version to appear in e-Publications@Marquette. [Oxford University Press] does not grant permission for this article to be further copied/distributed or hosted elsewhere without the express permission from [Oxford University Press]. 
NOT THE PUBLISHED VERSION; this is the author's final, peer-reviewed manuscript. The published version may be accessed by following the link in the citation at the bottom of the page.

social identities and engage in re-rankings, are questions which are here left unaddressed.

It is also worth noting that treating $\mathbf{P I}_{\mathrm{j}}$ as the individual's objective function does not imply that individuals optimise or maximise personal identity as they would in the case of a standard utility function. The reflexive treatment of $\mathbf{P} \mathbf{I}_{\mathrm{j}}$ here is not readily conformable to an instrumental rationality framework, since instrumental rationality involves a means-ends relationship that typically presupposes given ends, while the idea that the individual reflexively takes the subject (in the form of $U_{j}$ ) as an object implies that $U_{j}$ is exposed to some form of evaluation and not taken merely as given. Thus, we might consider that $\mathbf{P} \mathbf{I}_{\mathrm{j}}$ employs what I have termed an obligation-based deontological rather than instrumental rationality if we focus on the manner by which individuals form associations with particular social groups. Akerlof and Kranton employ a psychological internalisation mechanism in their account of individual attachment to groups, and then apply a anxiety/cognitive dissonance minimisation reading to provide an instrumentally rational understanding of the utility function. But an alternative, distinctly social mechanism that explains how individuals might attach themselves to groups exists in philosophers' recent collective intentionality theory (e.g., Tuomela, 1995; Searle, 1995). In this theory, when individuals form collective intentions in interaction with others, they 'voluntarily bind' themselves to others through the content of those intentions, and this creates a sense of obligation by which they guide their behaviour in groups (Davis, 2003, ch. 7). On this view of association with others as social rather than psychological, a deontologically rational behaviour underlies the revised $U_{j}$ function in (3). Individuals no doubt still behave in an instrumentally rational way in a variety of contexts, but it may well be that instrumental rationality poorly captures their behaviour in relation to others, particularly as concerns how they manage their different social identities. For the $\mathbf{P I}_{\mathrm{j}}$ function, then, rationality would need to be seen as complex in combining in the individual two different and incommensurable types of behaviour.

\section{Akerlof and Kranton and recent economics}

The Akerlof-Kranton paper is an example of 'recent economics' understood as a set of new research strategies relying on imports from other sciences to produce departures from the traditional assumptions of neoclassical economics. Some of these departures have been more radical than others, and consequently threaten to disrupt that traditional framework. In other cases, new contents appear

Cambridge Journal of Economics, Vol. 31, No. 3 (May 2007): pg. 349-362. DOI. This article is @ [Oxford University Press] and permission has been granted for this version to appear in e-Publications@Marquette. [Oxford University Press] does not grant permission for this article to be further copied/distributed or hosted elsewhere without the express permission from [Oxford University Press]. 
NOT THE PUBLISHED VERSION; this is the author's final, peer-reviewed manuscript. The published version may be accessed by following the link in the citation at the bottom of the page.

essentially conformable to neoclassical theorising. And yet, in some cases, what may initially appear conformable to standard assumptions turns out to be more problematic than anticipated. The Akerlof-Kranton paper involves the insertion of non-economics content into economic analysis by means of its addition of a selfimage argument to the utility function, one of the mainstays of the neoclassical approach. Thus, on the surface, the paper seems to fall into the second category as involving a conformable import. However, I suggest the paper rather falls into the third set of cases. Because the social identity approach on which Akerlof and Kranton draw was developed in such a way as to preclude methodologically individualist forms of explanation, it made social categories as developed by social scientists its main vehicle for investigating social identity. This effectively foreclosed any analysis of how individuals happened to have particular social identities, or how they might organise their different social identities to create personal identities. Rather, the method of analysis employed by social identity theorists was to say, were a set of individuals to be classified in such-and-such a way, then how would their awareness of a particular social identity be likely to manifest 'accentuation effects', and so lead to such phenomena as stereotyping, ethnocentrism, prejudice and in-group bias. Akerlof and Kranton add the utility function as their representation of the individual to this analysis, but as that analysis lacks a means of explaining how individuals see any particular social identity as salient, their introduction of an identity concept into standard economics in conjunction with the utility function ends up having an ad hoc quality about it. But this in turn then raises questions regarding the representation of the individual in terms of the utility function, particularly whether that representation can provide a way of understanding personal identity. Given that utility function analysis apparently lacks a means of addressing the multiple selves/multiple utility function problem (Davis, 2003, pp. 63ff.), that Akerlof and Kranton recognise that individuals have multiple social identities casts doubt on whether any account of individual identity is available in their framework. Thus, an apparently unintended consequence of their particular import is to jeopardise the whole neoclassical framework.

My suggested inversion of their analysis, and reinterpretation of the utility function in non-psychological and social terms, meant to offer an alternative framework that begins from the assumption that social identity and personal identity are linked concepts. I also rely on importing a non-economics science contents into economics but, instead of psychology's social identity approach, I prefer importing sociology's interactionist view of individuals and society as not only more hospitable to a possible account of the linkages between the two identity concepts, but as also creating a framework for an account of individuals in

Cambridge Journal of Economics, Vol. 31, No. 3 (May 2007): pg. 349-362. DOI. This article is (C [Oxford University Press] and permission has been granted for this version to appear in e-Publications@Marquette. [Oxford University Press] does not grant permission for this article to be further copied/distributed or hosted elsewhere without the express permission from [Oxford University Press]. 
economics that would fill the vacuum left by neoclassical thinking now made apparent in connection with identity analysis that fails to say how an individual with many social identities is still one individual. However, the inversion of the AkerlofKranton analysis suggested here, it should be emphasised, advances a conception of the individual that is fundamentally different from their conception in two key respects. First, individuals are socially embedded rather than atomistic, in the sense that their very individuality is a function of their relations to others. Second, the account of rationality of socially embedded individuals is complex, in that it combines both deontological and instrumentally rational dimensions. Individuals appear to operate with categorically different types of decision logics, and this means that, if we are to see them as engaged in producing their personal identities, then this activity cannot be explained in terms of optimisation. Thus, from the perspective of this particular strategy for rebuilding the account of the individual in economics by means of the imports from other science described here, the departures from standard analysis are, in large degree, disruptive of that traditional framework.

The author is grateful to the referees of this journal for their insightful and helpful comments on a previous version of this paper

\section{References:}

Abrams D, Hogg M. , Identity and Social Cognition , 1999 Oxford Blackwell

Akerlof G, Kranton R. Economics and identity, Quarterly J ournal of Economics, 2000, vol. 115 3(pg. 715-53)

Akerlof G, Kranton R. I dentity and schooling: some lessons for the economics of education, Journal of Economic Literature, 2002, vol. 40December(pg. 1167-201)

Akerlof G, Kranton R. Identity and the economics of organizations, Journal of Economic Perspectives, 2005, vol. 191

Bandura A. Self-efficacy: toward a unifying theory of behavioral change, Psychological Review, 1977, vol. 84 (pg. 191-215)

Bandura A. , Self-efficacy: The Exercise of Control , 1997 New York Freeman

Barrett C. , The Social Economics of Poverty: On Identities, Communities, Groups, and Networks, 2005 London Routledge

Becker G. , Accounting for Tastes, 1996 Chicago University of Chicago

Cooley C. , Human Nature and the Social Order , 1902 New York

Crocker J, Wolfe C. Contingencies of self-worth, Psychological Review, 1995, vol. 108 (pg. 593-623)

Darity, W. Jr, Stewart, J. and Mason, P. forthcoming. The economics of identity: the origin and persistence of racial norms, Journal of Economic Behavior and Organizations

Cambridge Journal of Economics, Vol. 31, No. 3 (May 2007): pg. 349-362. DOI. This article is @ [Oxford University Press] and permission has been granted for this version to appear in e-Publications@Marquette. [Oxford University Press] does not grant permission for this article to be further copied/distributed or hosted elsewhere without the express permission from [Oxford University Press]. 
NOT THE PUBLISHED VERSION; this is the author's final, peer-reviewed manuscript. The published version may be accessed by following the link in the citation at the bottom of the page.

Davis J. Personal identity and standard economic theory, Journal of Economic Methodology, 1995, vol. 2 1(pg. 35-52)

Davis J., The Theory of the Individual in Economics, 2003 London Routledge

Davis J. The turn in economics: neoclassical dominance to mainstream pluralism?, Journal of Institutional Economics, 2006, vol. 2 1(pg. 1-20)

Davis J. Schmid B, Peters F. Identity and commitment: Sen's fourth aspect of the self, Rationality and Commitment Oxford Oxford University Press

Folbre N. , Who Pays for the Kids? , 1994 London Routledge

Heinrich J, Boyd R, Bowles S, Gintis H, Fehr E Camerer C., Foundations of Human Sociality: Ethnography and Experiments in 15 Small-scale Societies , 2004 Oxford Oxford University Press

Hogg M. Forgas J, Williams K, Wheeler L. Self-categorization and subjective uncertainty resolution: cognitive and motivational facets of social identity and group membership, The Social Mind: Cognitive and Motivational Aspects of Interpersonal Behavior , 2001 New York Cambridge (pg. 323-49)

Hogg M, Terry D, White K. A tale of two theories: a critical comparison of identity theory with social identity theory, Social Psychology Quarterly, 1995, vol. 58 (pg. 255-69)

Kirman A, Teschl M. On the emergence of economic identity, Revue de Philosophique économique, 2004, vol. 9 1(pg. 59-86)

LivetP. La pluralité cohérente des notions d' identité pour les sciences sociales, Revue de Philosophique économique, 2004, vol. 9 1(pg. 29-57)

Loury G., The Anatomy of Racial Inequality , 2002 Cambridge, MA Harvard University Press

Mason PL. Identity, markets, and persistent racial inequality, Review of Black Political Economy , 2004, vol. 32 1(pg. 13-36)

McCall G Simmons J., I dentities and interactions, 1978 New York Free Press

Mead G., Mind, Self, and Society , 1934 Chicago University of Chicago

Mischel W. Toward a cognitive social learning reconceptualization of personality, Psychological Review, 1973, vol. 80 (pg. 252-84)

Searle J., The Construction of Social Reality , 1995 New York Free Press

Sen A., Reason before Identity , 1999 New Delhi Oxford University Press

Sen A. Goals, commitment, and identity, Journal of Law, Economics and Organization , 1985, vol. 12 republished on pp. 206-24 in Rationality and Freedom, Cambridge, MA, Belknap Press, 2002

Sen A. Social identity, Revue de philosophie economique, 20049

Stets J, Burke P. Identity theory and social identity theory, Social Psychological Quarterly, 2000, vol. 63 (pg. 283-95)

Stryker S., Symbolic Interactionism: a Social Structural Version , 1980 Menlo Park, CA Benjamin/Cummings

Tajfel H. Quantitative judgment in social perception, British J ournal of Psychology, 1959, vol. 50 (pg. 16-29)

Tajfel H. Moscovici S. Social categorization, pp. 272-302, Introduction à la psychologie sociale, 1972, vol. Vol. 1 Paris Larousse

Cambridge Journal of Economics, Vol. 31, No. 3 (May 2007): pg. 349-362. DOI. This article is @ [Oxford University Press] and permission has been granted for this version to appear in e-Publications@Marquette. [Oxford University Press] does not grant permission for this article to be further copied/distributed or hosted elsewhere without the express permission from [Oxford University Press]. 
NOT THE PUBLISHED VERSION; this is the author's final, peer-reviewed manuscript. The published version may be accessed by following the link in the citation at the bottom of the page.

Tajfel H, Jaspars J, Fraser C. TajfelH. The social dimension in European social psychology, pp. 1-5, The Social Dimension, European Developments in Social Psychology , 1984, vol. Vol. 1 Cambridge Cambridge University Press

Thomas K. Stevens R. The defensive self: a psychodynamic perspective, Understanding the Self , 1996 Thousand Oaks, CASage

Tuomela R., The Importance of Us: A Philosophical Study of Basic Social Notions , 1995 Stanford Stanford University Press

Turner J. Lawler E. Social categorization and the self-concept: a social cognitive theory of group behavior, pp. 77-122, Advances in Group Processes: Theory and Research, 1985, vol. Vol. 2 Greenwich, CTJAl

Turner J, Hogg M, Oakes P, Reicher S, Wetherell M. Rediscovering the Social Group: A Self-Categorization Theory, 1987 Oxford Blackwell

${ }^{1}$ Early contributions are Sen (1985), Folbre (1994), Davis (1995). More recent attention to identity has come from Akerlof and Kranton (2000, 2002, 2005), Barrett (2005), Darity et al. (forthcoming), Davis (2003, 2006), Livet (2004), Loury (2002), Kirman and Teschl (2004), Mason (2004) and Sen (1999, 2004).

${ }^{2}$ For a synthetic overview of the social identity approach, see Hogg et al. (1995).

${ }^{3}$ For a synthetic overview of the sociological approach to identity, see Stets and Burke (2000).

${ }^{4 T}$ he quoted passage is from Thomas' textbook (1996, p. 284).

${ }^{6}$ return to this point in connection with Akerlof and Kranton's adoption of the social identity approach below.

${ }^{7}$ For further details, see the two surveys cited in $\mathrm{fn} .1$ and 2 .

${ }^{8}$ Mead's traditional approach, known as the situational approach, assumes social structures are continuously transformed, and thus relatively unstable.

${ }^{9}$ The argument dates back in slightly different form to J ohn Locke, and was seen by his own commentators and more recently contemporary philosophers to be circular. I discuss Locke's argument and the one based on the utility function in more detail in Davis (2003, ch. 3).

${ }^{10}$ The argument in Davis (2003, pp. 145ff.) is that the reflexive stance individuals take in interactive contexts escapes the circularity problem that utility function analysis encounters (in regard to individuals knowing their own preferences) in virtue of individuals in such contexts taking themselves as single objects in light of others doing so.

Cambridge Journal of Economics, Vol. 31, No. 3 (May 2007): pg. 349-362. DOI. This article is @ [Oxford University Press] and permission has been granted for this version to appear in e-Publications@Marquette. [Oxford University Press] does not grant permission for this article to be further copied/distributed or hosted elsewhere without the express permission from [Oxford University Press]. 